\title{
Influence of a vegetable fat blend on the texture, microstructure and sensory properties of kashar cheese
}

\author{
By N. Dinkçi, ${ }^{a}$ * H. Kesenkaş, ${ }^{a}$ A.K. Seçkin, ${ }^{b}$ Ö. Kınık ${ }^{a}$ and S. Gönç ${ }^{a}$ \\ ${ }^{\text {a }}$ Ege University Faculty of Agriculture Department of Dairy Technology, \\ 35100 Bornova - Izmir, TURKEY \\ ${ }^{\mathrm{b}}$ Celal Bayar University Faculty of Engineering Department of Food Engineering, \\ 45140 Muradiye - Manisa, TURKEY \\ ( ${ }^{*}$ Corresponding author: nayil.dinkci@ ege.edu.tr)
}

\begin{abstract}
RESUMEN
Influencia de una mezcla de grasas vegetales en la textura, microestructura y propiedades sensoriales del queso Kashar.

La posibilidad de usar una mezcla de grasas vegetales comerciales en queso Kashar fue investigada. Los quesos Kashar fueron elaborados con una mezcla de grasas vegetales (VF) en lugar de grasa de leche (MF). Quesos Kashar con leche entera fueron también elaborados para comparar las características sensoriales, de color, de fusión, microestructurales y de textura durante el periodo de maduración de 90 días. El uso de grasas vegetales decreció la dureza y las propiedades de fusión, de cohesión, de gomosidad y de masticación e incremento la adhesividad mientras que la elasticidad no fue afectada. Las diferencias se hicieron menos notables hacia el final de la maduración. La micrografía electrónica de barrido de quesos VF mostro una red compacta con pequeños y uniformes glóbulos de grasa embebidos en la matriz de proteínas. Los quesos MF exhibieron una matriz de proteínas abierta conteniendo glóbulos de grasa de leche de varios tamaños y formas. El análisis del color demostró significativas diferencias entre los quesos. Finalmente, todas las características sensoriales del queso fueron afectadas por la mezcla de grasas vegetales.
\end{abstract}

PALABRAS CLAVE: Análisis del perfil de textura - Color - Grasa vegetal - Microscopía electrónica de barrido - Queso kashar.

\section{SUMMARY}

Influence of a vegetable fat blend on the texture, microstructure and sensory properties of kashar cheese.

The possibility of using a commercial vegetable fat blend in Kashar cheese was investigated. Kashar cheeses were manufactured by replacing the milk fat (MF) with a vegetable fat (VF) blend. Kashar cheeses from whole milk were also manufactured to compare textural, microstructural, meltability, color and sensory characteristics during a ripening period of 90 days. The use of vegetable fat decreased the meltability, hardness, cohesiveness, gumminess and chewiness of the cheese; while increasing adhesiveness where springiness was not affected. Differences became less notable toward the end of ripening. Scanning electron micrographs displayed VF cheese with a compact network with small and uniform fat globules embedded in the protein matrix. The MF cheese exhibited an open protein matrix containing milk fat globules of various sizes and forms. The color analysis demonstrated significant differences between cheeses. Finally, all sensory characteristics of the cheese were affected by the vegetable fat blend.

KEY-WORDS: Colour - Kashar cheese - Scanning electron microscope - Texture profile analysis - Vegetable fat.

\section{INTRODUCTION}

This work represents the continuation of a previous study (Kesenkas et al., 2009) where the effects of replacing milk fat with a commercial vegetable fat blend on gross composition, organic acid contents and fatty acid profiles of Turkish kashar cheese were defined. In this second part, the results from textural, microstructural and sensory analyses are presented. In the first part, it was determined that mainly the $\mathrm{pH}$, total solids and cholesterol content in the initial composition of the cheese were affected by the replacement of milk fat with a vegetable fat blend. There were also differences in the acid degree value and tyrosine contents. The organic acid concentrations of both cheeses changed during ripening except for citric and oxalic acids. Palmitic acid was the dominant fatty acid in MF cheese while the most abundant fatty acids in VF cheese were palmitic and oleic acid. The higher unsaturated fatty acid composition of VF cheese has attracted attention from the healthy food image point of view.

Consumers are becoming increasingly aware of the relationship between diet and health. One of the foremost concerns in this regard relates to the consumption of fat from foodstuffs, including cheese and other dairy products (Kavas et al., 2004, Hennelly et al., 2006). According to Mukherjee and Mitra (2009) Palm oil raises plasma cholesterol only when an excess of dietary cholesterol is present in the diet. It stimulates the synthesis of protective HDL cholesterol and the removal of harmful LDL cholesterol. Palm oil is rich in vitamin $E$ which appears to reduce serum cholesterol concentrations 
and has potent anti-oxidant effects. The aim of this study was to investigate a Kashar-like cheese with a vegetable fat blend that shows similar textural properties to Kashar cheese. Imitation cheese can be used in a number of different forms, e.g. slices, shreds, blocks and as an ingredient in many products, e.g. pizzas, pies and sauces (Noronha et al., 2007). Imitation cheese or cheese analogues are usually defined as cheese like products made by blending individual constituents, including nondairy fats or proteins to form a cohesive cheeselike mass (Noronha et al., 2008). The functional characteristics such as meltability and textural properties are important attributes that influence the quality and end use of imitation and processed cheese (Floury et al., 2009). Such cheeses also have to be organoleptically acceptable and exhibit textural properties similar to the full fat product. Kashar cheese is a Pasta Filata type cheese, which shows similarities with Caciocavallo, Provolone, Regusono, Kashkaval and partially with Mozzarella (Cetinkaya and Özütemiz 2006). It is the second most popular cheese in Turkey (Sahan et al., 2007). Its production is 45.730 tons per year in Turkey (Özdemir and Demirci 2006). In recent years, some studies have been carried out to investigate the affects of protein and/or carbohydrate based fat replacers in low fat Turkish cheeses (Kavas et al., 2004, Sahan et al., 2007, Koca and Metin 2004). However, the possibility of substituting milk fat with vegetable-based fats in Kashar-like cheese has not been explored extensively. Therefore, the objective of this study was to determine the effects of the replacement of milk fat with a commercial vegetable fat based on palm oil on the textural, microstructural and sensory properties of Kashar-like cheese.

\section{MATERIALS AND METHODS}

\subsection{Cheese Production}

The cheese samples were produced in an industrial dairy plant (Koyuncuoglu, Torbali, Izmir/ Turkey) as part of the standard production. The vegetable fat blend (Karlshamns $A B$, Sweden) was added (3.10\%) to skim milk. This milk was heated and homogenized at $55-60^{\circ} \mathrm{C}$ and 120 bar. Afterwards, the milk was pasteurized at $60^{\circ} \mathrm{C}$ for $20 \mathrm{~min}$, cooled to $32^{\circ} \mathrm{C}$ and $0.02 \% \mathrm{w} / \mathrm{v}$ of $\mathrm{CaCl}_{2} /$ $\mathrm{kg}$ was added. At this temperature, double strength rennet extract (Maxiren 180, DSM Food Specialties, Istanbul, Turkey) was used as clotting agent. The curd was cut with a curd knife in the shape of $1 \mathrm{~cm}$ cubes. The cut curd was allowed to settle for 10 min. The curds were milled at $\mathrm{pH}$ 5.90. Then the curd was melted in the presence of $\mathrm{NaCl}(400 \mathrm{~g} /$ $40 \mathrm{~kg}$ ) and trisodium citrate (300 g / $40 \mathrm{~kg}$ ) (DSM Food Specialties, Istanbul, Turkey) at $\mathrm{pH} 5.10$ in a cheese cooker (Stephan, Germany) using indirect steam injection at $85-90^{\circ} \mathrm{C}$ for $15 \mathrm{~min}$. The hot product was hooped and pressed overnight at ambient temperature. One block of cheese was approximately $1.5 \mathrm{~kg}$. The blocks of cheeses were vacuum, shrink packaged in Cryovac bags, and stored at $5^{\circ} \mathrm{C}$ for 3 months (VF). Cheese samples were taken for analyses on days 1, 30, 60 and 90 of storage. For comparison, a control cheese (MF) was also produced from milk containing $3.05 \%$ milk fat by the same process without homogenization. Finally, two different kashar cheeses (VF and MF) were obtained. The experiment was repeated three times.

\subsection{Textural Analyses}

Textural properties of the cheeses were measured with TA-XT plus Texture Analyzer (Vienna count, surrey GU7 1 YL, UK). Cylindrical cheese samples were obtained from the middle of the whole cheese block (2 $\mathrm{cm}$ diameter and $2.5 \mathrm{~cm}$ height). Cheese samples were wrapped with plastic stretch to prevent dehydration and tempered to $21^{\circ} \mathrm{C} \pm 1^{\circ}$. A two bite penetration test was performed using the Texture Analyzer with a P/35 probe (35 mm diameter) and operated at a crosshead speed of $1 \mathrm{~mm} / \mathrm{s}$ and penetration distance of $10 \mathrm{~mm}$ in both upward and downward directions with $10 \mathrm{sec}$ between the two cycles. Six textural parameters (hardness, adhesiveness, springiness, chewiness, gumminess and cohesiveness) were obtained from the analyses of these force-distance curves. All measurements were done in duplicate according to Awad et al. (2002).

\subsection{Microstructure}

Small pieces of cheese of $0.5 \mathrm{~cm}$ in diameter and 0.2 to $0.3 \mathrm{~cm}$ thickness were used for the scanning electron microscopy (SEM) analysis. The samples were fixed with Carnoy fluid at $4^{\circ} \mathrm{C}$ for $24 \mathrm{hr}$ and dehydrated using gradually increasing concentrations of ethyl alcohol (Graiver et al., 2004). The fixed and dehydrated samples were mounted on aluminum stubs using a double sided tape and then coated with a layer of gold (40-50 nm), allowing for surface and cross-section visualization. Micrographs of the samples were obtained from a scanning electron microscope (Philips XL-30S FEG). Each sample was viewed at magnification of 200x, 500x and 1000x. Representative micrographs were selected for presentation.

\subsection{Meltability}

Meltability of the cheese samples were determined by the Schreiber method (Koca and Metin 2004) with some modifications. The cheese samples were stored at $5^{\circ} \mathrm{C}$ until sample preparation. Samples were cut into $4 \mathrm{~mm}$ thick slices using a slicer (Robert Bosch $\mathrm{GmbH}$, Germany) and then into $41 \mathrm{~mm}$ diameter discs using a cork borer. The specimens were placed in a glass Petri dish (diameter $=100$ $\mathrm{mm}$ and height $=21 \mathrm{~mm}$ ) and put into an electric oven, preheated to $230^{\circ} \mathrm{C}$ for $5 \mathrm{~min}$. Then they were removed from the oven and cooled for $30 \mathrm{~min}$ at room temperature on a flat surface. The expansion of the cheese samples was measured by taking 6 
measurements around the circumference at equal angular directions as described by Altan et al. (2005). The average of the 6 readings was reported as the Schreiber meltability.

\subsection{Color Analysis}

The color of cheese samples was quantitatively determined using a Hunter lab colorimeter system (Hunter Lab, DP-9000, Hunter Associates Laboratory, Inc., Reston, VA, USA). Measurements were performed in triplicate for each treatment on non-overlapping areas of the cheese. The $L^{*}, a^{*}$ and $\mathrm{b}^{*}$ color dimensions were read for the cheese samples. Hue $\left(\mathrm{H}^{*}\right)$ angle and chroma $\left(\mathrm{c}^{*}\right)$ values were calculated from the $a^{*}$ and $b^{*}$ values. The Hunter $L^{*}$ value represents darkness from black (0) to white (100), the $a^{*}$ value represents color ranging from red $(+)$ to green $(-)$ and the $b^{*}$ value represents yellow $(+)$ to blue $(-)$. Hue is the color represented by red, yellow, green or blue or an intermediate between any contiguous pair of those for colors. Chroma is the saturation or intensity of the color.

\subsection{Sensory Evaluation}

The cheese samples were subjected to sensory evaluation by a panel of six members, from the Department of Dairy Technology at Ege University, familiar with Kashar cheese grading. Sensory evaluation was carried out with scoring tests according to the Turkish Standard TS 3272. The cheeses were evaluated for color, appearance, texture, flavor and overall acceptability. Water and bread were also provided to the panelists to rinse their mouths between samples.

\subsection{Statistical Analysis}

One way analysis of variance (ANOVA) was applied and whenever it was adequate Duncan's
Multiple Range Test was used in order to determine the differences between VF and MF cheeses. Also the effect of ripening on cheeses was subjected to this same analysis using SPSS $^{\odot} 9.05$ statistical package (SPSS Inc., Chicago, USA). In all cases 0.05 probability level was considered.

\section{RESULTS AND DISCUSSION}

\subsection{Chemical Composition}

The chemical characteristics of the cheeses were very similar; the fat in total solids contents of both cheeses did not significantly differ and met the legal specifications (Anonymous 1999) of a minimum of $45 \%(w / v)$ for full fat Kashar cheese. There were no significant differences in protein and salt contents between MF and VF cheeses. The total solid contents were very similar but statistically lower results were found for VF cheese. The $\mathrm{pH}$ value for VF cheese was significantly lower too. This can be attributed to the high free fatty acid contents of the vegetable fat blend. Both $\mathrm{pH}$ values are adequate for cheese to maintain its quality during ripening as mentioned by some researchers (Georgala et al., 2005, Van Nieuwenhove et al., 2007). The gross composition and $p$-values of the cheese samples can be found in the first part of the article in reference (Kesenkas et al., 2009).

\subsection{Texture Profile Analysis}

TPA is the most used imitative test to mimic the actions during chewing. The textural parameters can be calculated from a force-time TPA curve as described by Jooyandeh (2009). The changes in TPA parameters (hardness, cohesiveness, chewiness, adhesiveness, springiness and gumminess) during the storage period of the experimental cheeses are shown in Table 1.

Table 1

Effect of treatment and storage time on the uniaxial compression test values of MF and VF cheeses

\begin{tabular}{|c|c|c|c|c|c|c|c|}
\hline $\begin{array}{c}\text { Cheese } \\
\text { Type }\end{array}$ & Days & Hardness & Adhesiveness & Cohesiveness & Gumminess & Chewiness & Springiness \\
\hline \multirow{4}{*}{ MF } & 1 & $2.05 \pm$ & $1.11=$ & 153.07 & $.21 b c X$ & $22.69 \pm 2.11 \mathrm{bc} X$ & 0.03 \\
\hline & 30 & $2.47 \pm 0.41 c X$ & $1.07 \pm 0.02 \mathrm{aX}$ & $230.90 \pm 24.05 b X$ & $2.64 \pm 0.39 c X$ & $26.33 \pm 3.86 c X$ & 9.96 \\
\hline & 60 & $1.11 \pm 0.23 \mathrm{ax}$ & $1.29 \pm 0.05 b X$ & $184.13 \pm 24.05 a b$ & $1.42 \pm 0.26 \mathrm{aX}$ & $14.16 \pm 2.54 \mathrm{aX}$ & $9.96 \pm 0.01$ \\
\hline & 90 & $1.52 \pm 0.33 a b$ & $1.16 \pm 0.02 \mathrm{a}$ & $201.00 \pm 41.21 \mathrm{ab} X$ & $1.76 \pm 0.38 a b$ & $17.54 \pm 3.75 a b$ & $9.96 \pm 0.01$ \\
\hline \multirow{4}{*}{ VF } & 1 & $1.49 \pm 0.07 \mathrm{cY}$ & $1.10 \pm 0.02 \mathrm{a}$ & $114.73 \pm 13.75 \mathrm{Y}$ & $1.64 \pm 0.06 \mathrm{~b} \mathrm{Y}$ & $16.29 \pm 0.62 b Y$ & $9.95 \pm 0.05$ \\
\hline & 30 & $0.09 \mathrm{~b} \mathrm{Y}$ & $1.31 \pm 0.08 \mathrm{~b} Y$ & $137.03 \pm 12.67 Y$ & $1.25 \pm 0.12 b \mathrm{~b}$ & $12.59 \pm 0.9 b Y$ & $9.97 \pm 0.01$ \\
\hline & 60 & $0.44 \pm 0.04$ a Y & $1.61 \pm 0.05 c Y$ & $152.35 \pm 3.38$ & $0.71 \pm 0.06$ a $Y$ & $7.06 \pm 0.63 \mathrm{a} Y$ & $9.96 \pm 0.02$ \\
\hline & 90 & $1.00 \pm 0.37 b$ & $1.30 \pm 0.12 b$ & $98.41 \pm 46.83 Y$ & $1.35 \pm 0.38 b$ & $13.32 \pm 3.82 b$ & $9.92 \pm 0.04$ \\
\hline
\end{tabular}

a, b, c Means in the same column with different superscripts within cheese type are significantly different $(P<0.05)$. $X, Y$ Means in the same column and at the same age with different superscripts are significantly different $(P<0.05)$. 
Hardness is the force necessary to attain a given deformation. In sensory terms, it is the force necessary to compress cheese between the molar teeth (Chevanan et al 2006).

The highest hardness value of MF was seen on day 30 , as 2.47 whereas the highest hardness value of VF was seen on day 1 as 1.49. For MF samples hardness changed irregularly during storage. These changes were found significant $(p<0.05)$. The difference between the samples was significant except for on the $90^{\text {th }}$ day of storage. For VF samples hardness decreased reguraly until day 60 . Then it increased until the end of the storage period. The hardness values of both samples decreased at the end of ripening compared to the initial values in a ratio of about $25 \%$ for MF and $35 \%$ for VF samples. At the end of storage the hardness of the MF sample was 1.52 while for the VF sample it was determined as 1.00 . The cheese containing vegetable fat was significantly softer than the cheese with whole fat $(p<0.05)$. This is not surprising since fat breaks up the protein matrix and plays the role of lubricant to provide smoothness and a softer texture. As observed in our study, these results are caused by the fat type proteolysis degree during ripening and produce the differences in $\mathrm{pH}$ or moisture content observed in these cheeses (Upreti et al., 2006).

Adhesiveness is the work required to overcome the attraction force between the cheese and the contact surfaces of the universal testing machine (Chevanan et al 2006). In sensory terms, this force is required to remove the material that adheres to the mouth, especially the palate, during the normal eating process. According to adhesiveness, food materials may be classified into sticky, tacky and gooey categories (Chevanan et al., 2006). Initially the adhesiveness values of MF and VF samples were 1.11 and 1.10 , respectively. The adhesiveness value of MF changed very slightly. This value reached its highest level (1.29) on day 60 and then decreased at the end of storage to 1.16. For MF the storage process affected the adhesiveness on the $60^{\text {th }}$ day only. The adhesiveness did not significantly change on the $1^{\text {st }}$ or the $90^{\text {th }}$ day of ripening for the cheese containing vegetable fat or whole fat $(p<0.05)$. As a result the observed differences in adhesiveness may be related to the differences in cheese $\mathrm{pH}$, proteolysis degree between cheese samples and the different polar characteristics of the fat used (Chevanan et al., 2006, Lobato-Calleros and Vernon-Carter 1998). For the VF sample the adhesiveness reached its highest level (1.61) on the $60^{\text {th }}$ day of ripening. Then it decreased to 1.30 . The storage period affected the adhesiveness value of the VF and MF samples statistically $(p<0.05)$. Significant differences were found between the cheeses (MF and VF) only at the $30^{\text {th }}$ and $60^{\text {th }}$ days of storage for the adhesiveness values ( $p<0.05$ ).

Cohesiveness is a measurement of the extent to which the cheese can be deformed before it ruptures. In sensory terms, it is the degree to which a substance is compressed between the teeth before it breaks. In cheese, cohesiveness is a measurement of the strength of the internal bonds of the protein mycelium (Chevanan et al., 2006). The initial cohesiveness value of the MF samples was 153.07 and then it sharply increased to its highest value as 230.90 on the $30^{\text {th }}$ day of storage. The cohesiveness value showed some fluctuations during the storage period for the MF sample. The cohesiveness of VF was 114.73 at the beginning of storage. It increased steadily to its highest value of 152.35 on the $60^{\text {th }}$ day. Finally it decreased to 98.41 at the end of storage. Statistically, the storage period did not affect the cohesiveness value of the VF sample. The difference between samples was significant except for on the $60^{\text {th }}$ day of storage $(p<0.05)$. The cohesiveness of the cheese containing milk fat was much higher than its corresponding vegetable fat treatments throughout ripening. The greatest difference occurred after 90 days of ripening when the milk fat containing cheeses had $51.24 \%$ higher cohesiveness values than the VF cheeses. These differences might be due to the linkages by VF and MF which had varied casein intermolecular associations in the cheese paracasein network, the differences in the hydrophobic characteristics of the fat types used or the type of cheese and production techniques. Awad et al. (2002) found that the cohesiveness of cheese samples decreased during ripening; while Özer et al. (2003) and Tamime et al. (1999) claimed that the cohesiveness values of samples increased during storage.

These results are in agreement with the results observed by Pereira et al. (2005) and Liu et al. (2008). The highest gumminess values of the MF and VF samples were determined as 2.64 on the $30^{\text {th }}$ day and 1.64 on the $1^{\text {st }}$ day of storage respectively. Gumminess values changed irregularly during ripening and these differences were statistically significant for both samples $(p<0.05)$ except for on the $90^{\text {th }}$ day of ripening. A different fat base also showed effects on the gumminess value of cheese types. The samples with vegetable fat had significantly higher gumminess values than those with milk fat $(p<0.05)$. The results show that the addition of vegetable fat did not improve the protein matrix of the cheese but milk fat improved its textural properties. It is also reasonable to state that the vegetable fat had the potential to imitate the role of fat in cheese, but further research is needed on the proper preparation in order for vegetable fat to act as a fat source in cheese varieties.

Chewiness is a secondary textural parameter of cheese. It is a measurement of the energy required to masticate cheese into a uniform state before swallowing. In sensory terms, it is the energy required to disintegrate the cheese and to change it to a consistency suitable for swallowing. The chewiness values of the MF and VF samples were 22.69 and 16.29, respectively, at the beginning of storage and the chewiness of MF was about 30\% higher than VF samples. The highest chewiness was 
found on the $30^{\text {th }}$ day for the MF sample as 26.33 while for the VF samples, the maximum value was determined on the $1^{\text {st }}$ day as 16.29 . It can be said that the chewiness of all cheese samples decreased during the 2 months of ripening and increased slightly at the end of storage. The statistical analysis demonstrated that the type of fat and ripening time had significant effects on the chewiness of the cheese samples (Table 1). Chewiness is a secondary TPA parameter and depends on hardness, cohesiveness and springiness. The level of proteolysis, type of fat source and polar properties, residual lactose content and moisture / dry matter ratio of cheeses may have caused the differences in chewiness values in these treatments (Chevanan et al., 2006, Pereira et al., 2005, Liu et al., 2008). Statistically, the storage period and the production method affected the chewiness values of both samples significantly ( $p<0.05)$.

Springiness is a measurement of the recovery of the original undeformed condition after the first compression force is removed during a TPA test. In sensory terms, it is the degree to which a product returns to its original shape once it is compressed between the teeth. Based on springiness, food materials are classified as either elastic or plastic (Chevanan 2006). The springiness values observed might be related to cross-linkages in the protein matrix, proteolysis degree, moisture content in cheese samples and the crystal fat globules which could contribute to the firm structure of the VF cheese (Chevanan et al., 2006, Uprety et al., 2006, Pereira et al., 2005, Liu et al., 2008). As it can be seen from Table 1 very close results were obtained for springiness values for both samples throughout the storage period.

\subsection{Microstructure}

Every cheese variety has its characteristic structural features, which reflect the biochemical changes in the cheese (Madadlou et al., 2005). Microstructure studies provide strategic information to understand and therefore to control cheese properties (Lobato-Calleros and Vernon-Carter 1998). Representative scanning electron micrographs of the (MF) control cheese at 200x, 500x and 1000x magnifications are presented in Fig. 1. Control cheese (MF) exhibited an open protein matrix containing milk fat globule voids of various sizes and forms. The holes in the protein matrix indicate the spaces occupied by fat globules before extraction. Granular structures attributed to deposited casein micelles and casein chains can be seen on the surface (Fig.1c).

The SEM micrographs of VF cheese at the same magnifications are present in Fig. 2. The complete substitution of milk fat by emulsified vegetable fat conferred noticeably different structural characteristics. The VF cheese showed a compact network. The fat globules were smaller, more uniform in size and embedded in the protein matrix in these cheese samples. This could be explained by the homogenization step during the production of VF cheese. The homogenization of cheese milk creates smaller fat globules and disperses these more evenly in a more compact protein matrix (Everett and Auty 2008). Some vegetable oil droplets can be observed in Figs. $2 b$ and $2 \mathrm{c}$. The fact that they are observable by SEM shows that they must have been covered by a protein layer that was fixed during sample preparation. This is in agreement with the findings of Lobato-Calleros et al. (2007).

\subsection{Meltability}

Cheese meltability is an important functional property especially for cheeses used in foods consumed after heat treatment (Altan et al., 2005). Meltability in Kashar cheese is very important because these cheeses are used as an ingredient in sandwiches and pizzas in Turkey (Koca and Metin 2004). As can be seen in Table 2, the MF cheese had significantly better meltability than the VF cheese during the whole ripening period $(p<0.05)$. This finding is consistent with those of Azzam (2007) who showed that the meltability of freshly processed cheese containing palm stearin was significantly lower than the control cheese with milk fat and the other treatments like sunflower oil and coconut oil. This may be due to the high melting point of palm stearin, which is the ingredient of the vegetable fat blend (Hui 1996). Similar results were observed for Kashar cheese produced with different fat replacers (Sahan et al., 2007, Koca and Metin 2004). This results also indicates that during the storage period there was no significant $(P<0.05)$ change in the meltability values of the cheeses as observed by Koca and Metin (2004). In contrast to our study, Sahan et al. (2007) reported that during storage the meltability of cheese increased.

Table 2

Effect of treatment and storage time on the meltability values of MF and VF cheeses

\begin{tabular}{ccc}
\hline Cheese Type & Days & Schreiber Test \\
\hline \multirow{3}{*}{ MF } & 1 & $7.75 \pm 0.22 \mathrm{~b} \mathrm{X}$ \\
& 30 & $7.05 \pm 0.20 \mathrm{~b} \mathrm{X}$ \\
& 60 & $5.64 \pm 0.55 \mathrm{a} \mathrm{X}$ \\
& 90 & $7.34 \pm 1.10 \mathrm{~b} \mathrm{X}$ \\
\hline \multirow{3}{*}{ VF } & 1 & $5.61 \pm 0.34 \mathrm{~b} \mathrm{Y}$ \\
& 30 & $5.41 \pm 0.30 \mathrm{~b} \mathrm{Y}$ \\
& 60 & $4.57 \pm 0.30 \mathrm{a} \mathrm{Y}$ \\
& 90 & $5.73 \pm 0.33 \mathrm{~b} \mathrm{X}$ \\
\hline
\end{tabular}

a, b Means in the same column with different superscripts within cheese type are significantly different $(P<0.05)$.X, Y Means in the same column and at the same age with different superscripts are significantly different $(P<0.05)$. 

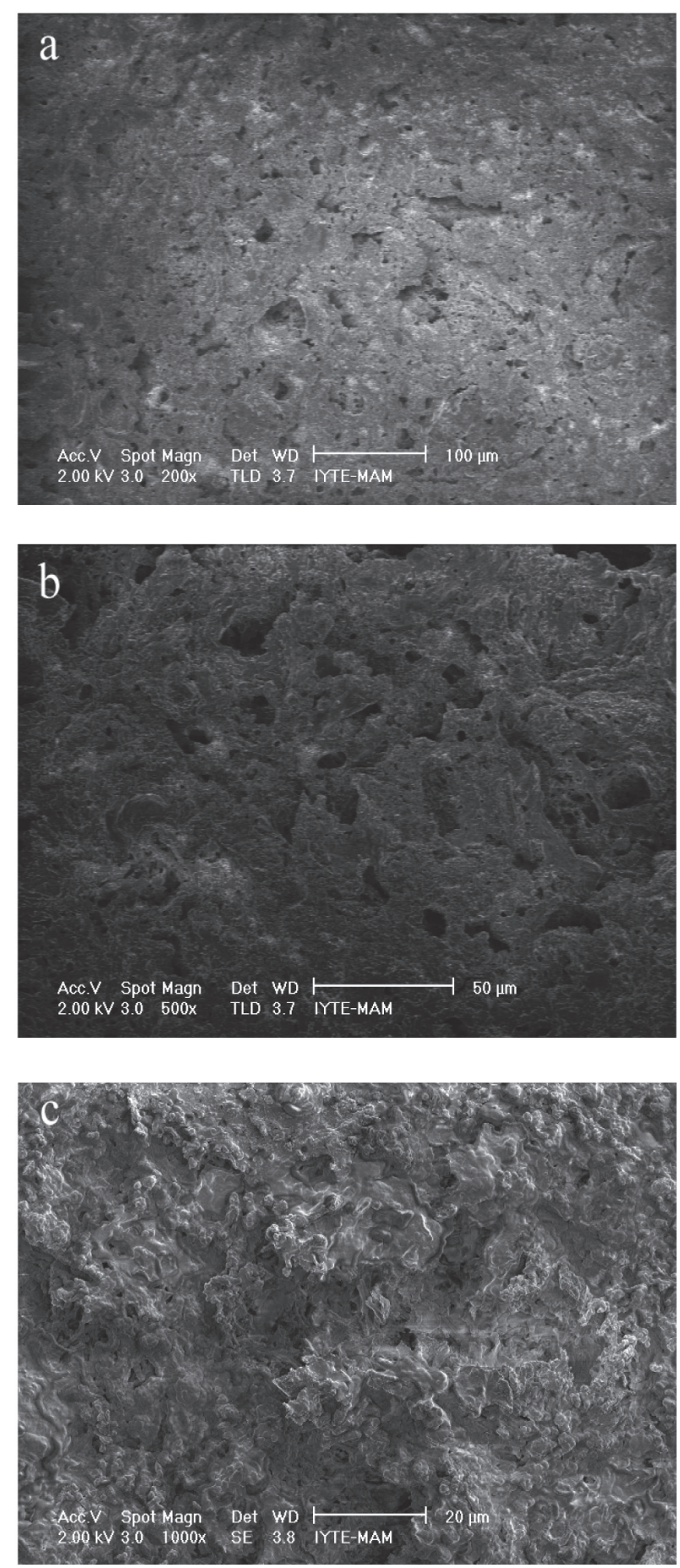

Figure 1

Scanning electron micrographs of MF cheese at (a) 200x, (b) 500x and (c) 1000x.

\subsection{Color}

The visual descriptive panel with the cheese samples indicated that the results demonstrate a significant difference in the exterior color. As shown in Table 3, MF samples were darker than cheeses containing vegetable fat. The $L^{*}$ values which measure degree of white (100) to black (0) of the samples varied from 87.07-92.31 initially and 85.38$87.25,91.48-91.83$ at the $1^{\text {st }}$ and $3^{\text {rd }}$ months of the
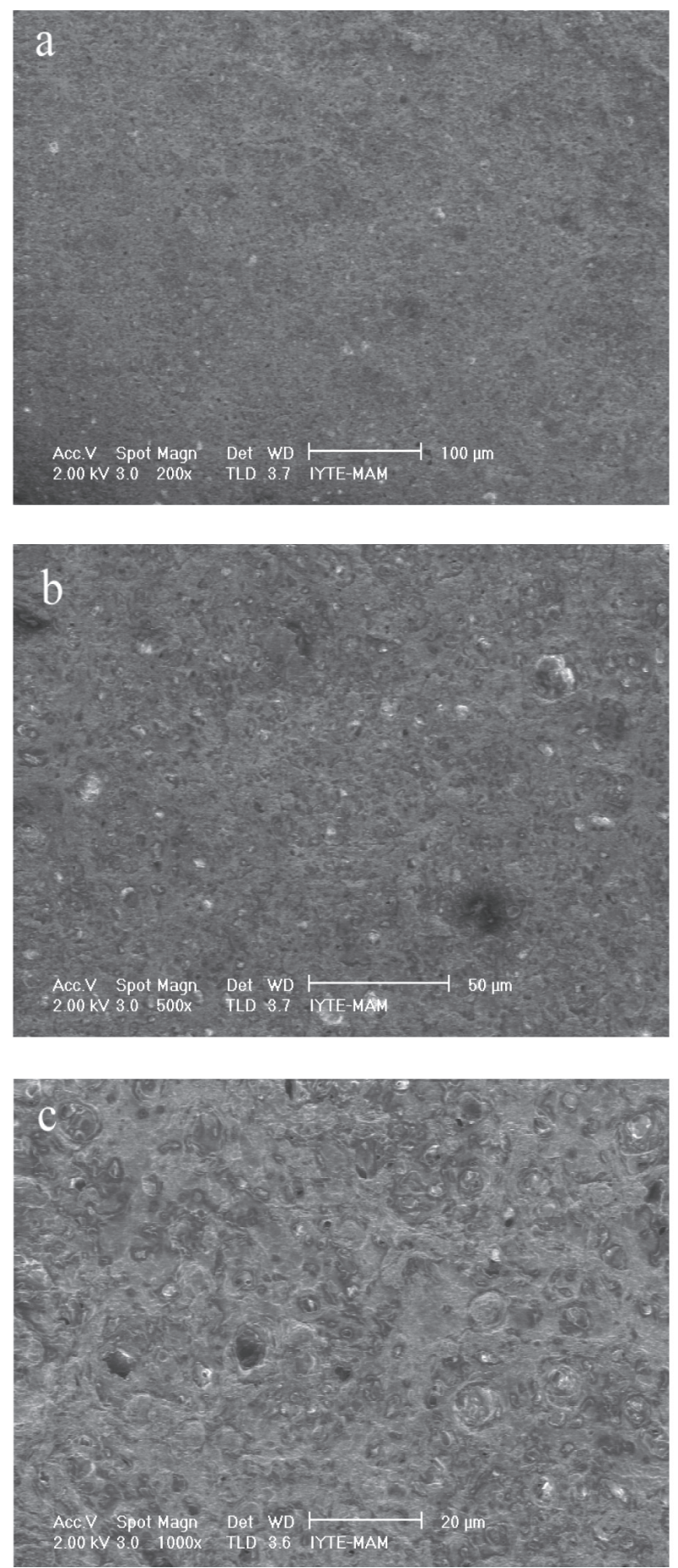

Figure 2

Scanning electron micrographs of VF cheese at (a) 200x, (b) 500x and (c) 1000x.

ripening period. Changes in $L^{*}$ values were apparent as the storage period progressed $(p<0.05)$ where cheeses containing milk fat became darker. This fact may be attributed to the Maillard browning reaction that occurs during storage between lactose and cheese protein especially casein (Azzam 2007).

Also there were significant differences in the $b^{*}$ value between MF and VF samples $(p<0.05)$. On the other hand the $\mathrm{a}^{*}$ value did not show a definite 
trend throughout ripening. During the storage of the cheese samples, the intensity of yellow color showed a slight increase. This might be attributed to a decrease in the moisture content during the ripening period. These findings are usually in agreement with some data determined by several researchers (Azzam 2007, Abd-Rabou et al., 2005, Olson et al., 2007). Moreover, previous study on cheese color as a function of ripening time by Rohm and Jaros (1996) reported a decrease for $L^{*}$ value and an increase for $a^{*}$ and $b^{*}$ values during the ripening of Emmental cheese. Ginzinger et al. (1999) and Buffa et al. (2004) reported that the yellowness index of cheese color highly correlated with the $b^{*}$ value, increasing as cheese ripened and almost corresponded to the sensory difference threshold.

Table 3 shows the hue angle and chroma values for the VF and MF cheese samples. The hue angle and chroma values were significantly different between the VF and MF samples $(p<0.05)$. This is in agreement with the sensory scores, where the color of the MF cheese was defined as straw yellow and the VF cheese was creamy white. There was no significant difference in the $C^{*}$ value during the ripening period $(p<0.05)$. A slight increase in the $\mathrm{H}^{*}$ value after 30 days of ripening for the MF cheese and a decrease at the $90^{\text {th }}$ ripening day for the VF cheese could be stated statistically $(p<0.05)$.

\subsection{Sensory Evaluation}

The results of the sensory panel's assessment of cheese quality at the age of $1,30,60$ and 90 days are given in Table 4. The data showed that the color, appearance, texture, flavor and overall properties of Kashar cheeses made with the vegetable fat blend were significantly lower $(P<0.05)$ than those of the Kashar cheese containing only milk fat during the ripening period. However there were no differences between the flavor scores of cheeses except at the end of storage. Besides, all sensory characteristics of the cheeses were affected by storage $(P<0.05)$. The

Table 3

Effect of treatment and storage time on the color values of MF and VF cheeses

\begin{tabular}{|c|c|c|c|c|c|c|}
\hline $\begin{array}{c}\text { Cheese } \\
\text { Type }\end{array}$ & Days & $L^{*}$ & $a^{*}$ & $\mathbf{b}^{*}$ & $c^{*}$ & $\mathbf{H}^{*}$ \\
\hline \multirow{4}{*}{ MF } & 1 & $87.07 \pm 0.22 b c X$ & $-1.11 \pm 0.14 X$ & $19.78 \pm 0.45 \mathrm{ax}$ & $19.81 \pm 0.46 X$ & $93.20 \pm 0.33$ a X \\
\hline & 30 & $86.82 \pm 0.14 b X$ & $-0.75 \pm 0.09 x$ & $19.32 \pm 0.1 \mathrm{a} X$ & $20.69 \pm 0.48 X$ & $93.84 \pm 0.18 b X$ \\
\hline & 60 & $87.25 \pm 0.16 c X$ & $-1.40 \pm 0.48$ & $21.14 \pm 1.02 b x$ & $21.19 \pm 1.03 x$ & $94.06 \pm 0.19 b X$ \\
\hline & 90 & $85.38 \pm 0.18 \mathrm{a} \mathrm{X}$ & $-1.30 \pm 0.12$ & $20.42 \pm 0.49 a b X$ & $20.46 \pm 0.48 X$ & $93.65 \pm 0.41 \mathrm{ab} X$ \\
\hline \multirow{4}{*}{ VF } & 1 & $92.31 \pm 0.18 Y$ & $-1.88 \pm 0.05$ a $Y$ & $13.78 \pm 0.35 a b Y$ & $13.91 \pm 0.35 Y$ & $97.78 \pm 0.02 b \mathrm{~b}$ \\
\hline & 30 & $91.48 \pm 0.75 Y$ & $-1.25 \pm 0.07 b \mathrm{y}$ & $13.41 \pm 0.06$ a $Y$ & $14.86 \pm 0.18 Y$ & $97.82 \pm 0.12 b \mathrm{Y}$ \\
\hline & 60 & $91.83 \pm 0.28 Y$ & $-1.36 \pm 0.14 b$ & $14.58 \pm 0.3 b \mathrm{y}$ & $14.64 \pm 0.28 Y$ & $98.11 \pm 0.23 b Y$ \\
\hline & 90 & $91.74 \pm 0.5 Y$ & $-1.29 \pm 0.11 b$ & $14.55 \pm 0.7 b Y$ & $14.61 \pm 0.69 Y$ & $95.10 \pm 0.61 \mathrm{a} Y$ \\
\hline
\end{tabular}

a, b, c Means in the same column with different superscripts within cheese type are significantly different $(P<0.05) . \mathrm{X}, \mathrm{Y}$

Means in the same column and at the same age with different superscripts are significantly different $(P<0.05)$.

Table 4

Effect of treatment and storage time on the sensory characteristics of MF and VF cheeses

\begin{tabular}{crlllll}
\hline $\begin{array}{c}\text { Cheese } \\
\text { Type }\end{array}$ & \multicolumn{1}{l}{ Days Colour } & \multicolumn{1}{l}{ Appearance } & Texture & \multicolumn{2}{l}{ Flavor } & \multicolumn{2}{l}{ Overall } \\
\hline & 1 & $9.40 \pm 0.00 \mathrm{bX}$ & $28.80 \pm 1.20 \mathrm{bX}$ & $19.20 \pm 0.80 \mathrm{bX}$ & $37.93 \pm 0.81 \mathrm{bX}$ & $95.33 \pm 1.81 \mathrm{bX}$ \\
$\mathrm{MF}$ & 30 & $9.59 \pm 0.08 \mathrm{bX}$ & $29.29 \pm 0.08 \mathrm{bX}$ & $19.17 \pm 0.14 \mathrm{bX}$ & $36.80 \pm 0.38 \mathrm{bX}$ & $94.84 \pm 0.61 \mathrm{bX}$ \\
& 60 & $9.13 \pm 0.23 \mathrm{aX}$ & $29.50 \pm 0.00 \mathrm{bX}$ & $19.13 \pm 0.46 \mathrm{bX}$ & $36.87 \pm 0.42 \mathrm{bX}$ & $94.40 \pm 0.20 \mathrm{bX}$ \\
& 90 & $9.11 \pm 0.10 \mathrm{aX}$ & $26.83 \pm 0.17 \mathrm{a}$ & $18.11 \pm 0.19 \mathrm{aX}$ & $31.00 \pm 1.46 \mathrm{a}$ & $85.06 \pm 1.63 \mathrm{aX}$ \\
\hline & 1 & $6.80 \pm 0.00 \mathrm{aY}$ & $26.47 \pm 0.12 \mathrm{dY}$ & $16.47 \pm 0.46 \mathrm{cY}$ & $30.47 \pm 0.23 \mathrm{cY}$ & $80.20 \pm 0.20 \mathrm{bY}$ \\
$\mathrm{VF}$ & 30 & $7.34 \pm 0.08 \mathrm{cY}$ & $23.50 \pm 0.13 \mathrm{cY}$ & $13.38 \pm 0.78 \mathrm{bY}$ & $24.38 \pm 0.98 \mathrm{aY}$ & $68.59 \pm 1.54 \mathrm{aY}$ \\
& 60 & $7.00 \pm 0.00 \mathrm{bY}$ & $21.50 \pm 0.00 \mathrm{aY}$ & $14.47 \pm 0.61 \mathrm{bY}$ & $26.73 \pm 0.95 \mathrm{bY}$ & $68.87 \pm 1.55 \mathrm{aY}$ \\
& 90 & $7.13 \pm 0.10 \mathrm{bY}$ & $21.95 \pm 0.39 \mathrm{~b}$ & $11.76 \pm 1.06 \mathrm{aY}$ & $29.28 \pm 1.26 \mathrm{c}$ & $68.83 \pm 0.76 \mathrm{aY}$ \\
\hline
\end{tabular}

a, b, c Means in the same column with different superscripts within cheese type are significantly different $(P<0.05)$. X, Y

Means in the same column and at the same age with different superscripts are significantly different $(P<0.05)$ 
color of the MF cheeses was defined as "straw yellow or dark straw yellow" by panelists whereas the VF cheeses were "creamy white". This is in agreement with the color analysis; where during the whole ripening stage the MF and VF cheeses were statistically different $(p<0.05)$. It should be noted that yellowish Kashar cheese is more desirable to consumers. The appearance of the MF cheeses was considered as more uniform, smoother and brighter. Conversely, the cheeses containing the vegetable fat blend had an opaque appearance. The good textural quality of the MF cheeses was probably due to their milk fat content. It is well-known that textural defects are the main problems caused by a fat reduction in cheeses. So it is clear that the addition of the vegetable fat blend was not successful in overcoming this defect in this study. Regarding flavor, scores for the cheeses containing milk fat were significantly higher than those of the cheese made with a vegetable fat blend $(p<0.05)$. Although there are several factors affecting the flavor of Kashar cheese, the differences between flavor scores can be mainly related to a difference in short-chain fatty acid compositions because the short-chain fatty acid (C4:0-C12:0) contents of the MF cheese were higher than the VF cheese (results not shown). Guler (2005) reported that the higher concentrations of short-chain fatty acids especially the caproic acid in Kashar cheese could increase the flavour intensity. The difference between the overall acceptability of Kashar cheese was significant and both scores were at their maximum at day 1 of storage. The results for both cheeses show that all the sensory features of cheeses were positively affected by overall acceptability in the same level according to the correlation among these properties $(\mathrm{P}<0.05)$. However, a negative correlation was found between color scores and overall acceptability for the VF cheeses $(P<0.05)$ whereas this correlation was insignificant for the MF cheeses.

The textural and sensory properties were correlated to find the relations between these properties. A significant and positive correlation was found between color scores of MF cheese and instrumental hardness, gumminess and chewiness $(\mathrm{P}<0.05)$. The texture and overall acceptability obtained by the sensory evaluation for the VF cheeses were negatively correlated with the TPA adhesiveness $(\mathrm{P}<0.05)$ but positively with TPA hardness $(P<0.05)$. It is the same for appearance scores, because in VF cheeses there was again a positive correlation between appearance and hardness but a negative one between appearance and adhesiveness $(P<0.05)$. This means that Kashar cheeses made with the vegetable fat blend which were harder and less adhesive had higher overall acceptability and appearance scores and were preferred by the panelists.

\section{CONCLUSIONS}

Textural tests showed significant differences between cheeses. The MF cheese was harder, more cohesive, gummier and chewier while the VF cheese was more adhesive. The microstructural analysis displayed that the VF cheese had a compact network with small and uniform fat globules embedded in the protein matrix. The microstructure of the MF cheese exhibited an open protein matrix containing milk fat globules of various sizes and forms. The color evaluation showed significant differences between cheeses related to the fat ingredient. The MF cheese also had a higher meltability and showed higher sensory scores during the whole ripening period but the VF cheese was organoleptically and texturally acceptable for consumption too. Some textural properties and color could be corrected by using different emulsifying salts and color ingredients. Further investigations are needed to prevent these defects.

\section{REFERENCES}

Abd-Rabou FH, Abd-El Fattah AM, El-Sayed MM, Mohamed AG. 2005. Improvement of nutritional value of processed cheese by using midified emulsifying salts. Egypt J. Dairy Sci. 33, 87-95.

Altan A, Turhan M, Gunasekaran S. 2005. Short Communication: Comparison of covered and uncovered schreiber test for cheese meltability evaluation. J. Dairy Sci. 88, 857-861.

Anonymous, 1999. Turkish standard: Kashar cheese, TS 3272, TSE, Bakanlıklar, Ankara, Türkiye.

Awad RA, Abdel-Hamid LB, El-Shabrawy SA, Sing RK. 2002. Texture and microstructure of block type processed cheese with formulated emulsifying salt mixture. Lebens. Wiss Technol. 35, 54-61.

Azzam MA. 2007. Effect of partial replacement of milk fat with vegetable oils on the quality of processed cheese spreads. Egypt J. Dairy Sci 35, 87-95.

Buffa M, Buenaventura G, Saldo J, Trujillo AJ. 2004. Changes in organic acids during ripening of cheeses made from raw, pasteurized or high-pressure-treated goats' milk. Lebens. Wiss Technol. 37, 247-253.

Cetinkaya F, Özütemiz GE. 2006. Microbiological and chemical changes throughout the manufacture and ripening of Kashar: a traditional Turkish cheese. Turk. J. Vet Anim. Sci. 27, 791-787.

Chevanan N, Muthukumarappan K, Upreti P, Metzger LE. 2006. Effect of calcium and phosphorus, residual lactose and salt-to-moisture ratio on textural properties of cheddar cheese during ripening. J. Texture Stud. 37, 711-730.

Everett DW, Auty AAE. 2008. Cheese structure and current methods of analysis. Int. Dairy J. 18, 759773.

Floury J, Benedicte C, Rousseau F, Lopez C, Tissier JP, Famelart MH. 2009. Reducing salt level in food: Part 1. Factors affecting the manufacture of model cheese systems and their structure-texture relationships. Lebensm-Wiss Technol. 42, 1611-1620.

Georgala A, Moschopoulou E, Aktypis A, Massouras T, Zoidou E, Kandarakis I, Anifantakis E. 2005. Evolution of lipolysis during the ripening of traditional feta cheese. Food Chem. 93, 73-80.

Ginzinger W, Jaros D, Lavanchy P, Rohm H. 1999. Raw milk flora affects composition and quality of bergkäse -3 . Physical and sensory properties, and conclusions. Lait 79, 411-421. 
Graiver NG, Zaritzky NE, Califano, AN. 2004. Viscoelastic behavior of refrigerated and frozen low moisture Mozarella cheese. J. Food Sci. 69/3, 123-128.

Guler Z. 2005. Quantification of free fatty acids and flavor properties in kasar cheeses. J. Food Lipids 12, 209 221.

Hennelly PJ, Dunne PG, O'Sullivan M, O’Riordan, ED. 2006. Textural, rheological and microstructural properties of imitation cheese containing inulin. $J$. Food Eng. 75, 388-395.

Hui, YH. 1996. Bailey's industrial oil and fat production. Vol. 3 ( $5^{\text {th }}$ ed.) Johnwiley and Sons, Inc, Canada.

Jooyandeh H. 2009. Effect of fermented whey protein concentration on texture of Iranian white cheese. J. Text. Stud. 40, 497-510.

Kavas G, Oysun G, Kinik O, Uysal H. 2004. Effect of some fat replacers on chemical, physical and sensory attributes of low fat white pickled cheese. Food Chem. 88, 381-388.

Kesenkas H, Dinkci N, Seckin AK, Kinik Ö, Gönc S. 2009. The effect of using a vegetable fat blend on some attributes of kashar cheese. Grasas Aceites 60 , 41-47.

Koca N, Metin M. 2004. Textural, melting and sensory properties of low fat fresh Kashar cheeses produced by using fat replacers. Int. Dairy J. 14, 365-373.

Liu H, Xu XM, Guo SD. 2008. Comparison of full fat and low fat cheese analogues with or without pectin gel through microstructure, texture, rheology, thermal and sensory analysis. Int J. Food Sci. Tech. 43, 15811592.

Lobato-Calleros C, Reyes-Hernandez J, Beristain IC, Hornelas-Uribe Y, Sanchez-Garcia JE, Vernon-Carter EJ. 2007. Microstructure and texture of White fresh cheese made with canola oil and whey protein concentrate in partial or total replacement of milk fat. Food Res. Int. 40, 529-537.

Lobato-Calleros C, Vernon-Carter EJ. 1998. Microstructure and texture of cheese analogs containing different types of fat. J. Texture Stud. 29, 569-586.

Madadlou A, Khosrawshahi A, Mousavi ME. 2005. Rheology, microstructure and functionality of low fat Iranian White cheese made with different concentrations of rennet. J. Dairy Sci. 88, 3052-3062.

Mukherhjee S, Mitra A. 2009. Health effects of palm oil. J. Hum. Ecol. 26 (3), 197-203.
Noronha N, Dolores O'Riordan E, O'Sullivan M. 2008. Influence of processing parameters on the texture and microstructure of imitation cheese. Eur. Food Res. Technol. 226, 385-393.

Noronha N, Dolores O'Riordan ED, O'Sullivan M. 2007. Replacement of fat with functional fibre in imitation cheese. Int. Dairy J. 17, 1073-1082.

Olson DW, Van Hekken DL., Tunick MH, Soryal KA, Zeng SS. 2007. Effects of aging on functional properties of caprine milk made into cheddar- and colby-like cheeses. Small Ruminant Res. 70, 218-227.

Özdemir C, Demirci M. 2006. Selected microbiological properties of Kashar cheese samples preserved with potassium sorbate. Int. J. Food Prop. 9, 515-521.

Özer BH, Robinson RK, Gradison SA. 2003. Textural and microstructural properties of Urfa cheese (a white brined Turkish cheese). Int. J. Dairy Technol. 56/3, 171-176.

Pereira RB, Bennett RJ, Luckman MS. 2005. Instrumental and sensory evaluation of textural attributes in cheese analogs: A correlation study. J. Sens. Stud. 20, 434-453.

Rohm H, Jaros D. 1996. Color of hard cheese - 1 . Description of color properties and effects of maturation. Z. Lebensm. Unters For 203, 241-244.

Sahan N, Yasar K, Hayaloğlu AA, Karaca OB, Kaya A. 2007. Influence of fat replacers on chemical composition, proteolysis, texture profiles, meltability and sensory properties of low-fat Kashar cheese. $J$. Dairy Res. 75, 1-7.

Tamime AY, Muir DD, Shenana ME, Kalab M, Dawood $\mathrm{AH}$. 1999. Processed cheese analogues incorporating fat substitutes rheology, sensory perception of texture and microstructure. Lebens. Wiss Technol. 32, 50-59.

Upreti P, McKay LL, Metzger LE. 2006. Influence of calcium and phosphorus, lactose and salt-to-moisture ratio on cheddar cheese quality: Changes in residual sugars and water soluble organic acids during ripening. J. Dairy Sc. 89, 429-443.

Van Nieuwenhove CP, Oliszewski R, Gonzalez SN, Chala ABP. 2007. Influence of bacteria used as adjunct culture and sunflower oil addition on conjugated linoleic acid content in buffalo cheese. Food Res. Int. 40 559-564.

Recibido: 23/09/10 Aceptado: $16 / 11 / 10$ 